\title{
中国主要城市群新增制造业用地特征 及城镇体系耦合分析
}

\author{
孙 伟 ${ }^{1}$, 金晓斌 ${ }^{1,2^{*}}$, 张志宏 ${ }^{1,3}$, 韩 娟 $^{1}$, 项晓敏 ${ }^{1}$, 周寅康 ${ }^{1,2}$ \\ (1. 南京大学地理与海洋科学学院, 南京 210023; 2. 南京大学自然资源研究中心, 南京 210023; \\ 3. 中国土地勘测规划院, 北京 100029)
}

\begin{abstract}
摘 要: 为探索中国典型城市群新增制造业用地结构与布局状况、发展及功能分工特征, 本文基于中国土地市场网 2009-2013 年制造业用地出让数据, 通过区位熵、耦合分析、相关分析等方法, 分析了长三角、珠三角、京津冀、长江 中游和成渝 5 个典型城市群新增制造业用地分布特征以及城镇体系耦合特征差异。结果表明: (1)各城市群新增制 造业用地差异显著。长三角、珠三角城市群新增制造业发展较为均衡; 京津冀、长江中游和成渝城市群发展协调性 仍有待提升。(2)新增制造业各行业用地在 5 个城市群中均呈现出一定的集聚特征, 其中原材料等传统产业倾向布 局在城市群边缘区及城市低等级区; 电子信息产业等新兴产业多集中在核心城市及高等级区。(3)各城市群内部新 增制造业用地市场化机制作用较为充分, 地价呈现随等级提升而递增的趋势; 城市群核心区市场活跃度较低而骨 干区较高。相关结论可为城市群产业布局调整、优化以及制定不同等级区域协调发展战略提供参考。
\end{abstract}

关 键 词:土地出让; 制造业; 新增用地; 耦合特征; 城市群; 中国

\section{1 引言}

在城镇化进程中,城市群以一个或多个中心城 市为核心向周围扩散,形成等级阶梯式的城市网 络, 并不断成为国家经济发展和城市化的主体(顾 朝林, 2011)。不同等级城市存在明显的要素禀赋和 资源稀缺差异, 核心城市通过产业分工等经济活动 融合周边城市(周霞, 2013)。城市群的形成和发展 吸引相关产业集聚, 客观地反映了区域产业结构和 布局, 而产业的集聚与扩散也推动了城市群中各等 级城市的发展 (马延吉, 2010), 城市群产业布局与地 域分工的调整优化则是推动城市群发展和竞争力 提升的决定性因素(国家发改委国地所课题组, 2009)。在中国, 工业制造业是城市发展和经济增 长的主要动力, 工业用地扩张是城市化推进的重要 途径之一(傅元海等, 2014), 制造业的结构和布局直
接关系到土地利用效率提升、经济结构转变、城市 功能互补与分工协作, 以及区域经济的持续健康 发展。

中国早期的工业化和城市化进程过分注重经 济增长和空间扩展等物质性推进, 出现诸多不利于 地区长期发展的城市化问题, 如工业用地市场违法 违规现象突出, 竞价机制市场化程度较低,市场机 制失范与中央政府的价格监管失灵并存; 城市群内 部发展不均衡, 核心城市产业集聚规模不足,边缘 城市土地低价低效利用, 浪费严重, 影响到地区稳 定, 以及资源、环境、经济的协调发展(党兴华等, 2007; 周霞, 2013)。分析城市群制造业宏观布局状 况, 把握城市群内部不同等级城市产业用地发展及 功能分工特点,探索城市群制造业发展机制与规律 是制定区域产业发展战略、优化产业结构和布局、 促进地区经济持续协调发展的重要途径。

收稿日期:2016-07;修订日期:2016-11。

基金项目: 教育部博士点基金项目(20120091110014) [Foundation: Ph.D. Programs Foundation of Ministry of Education of China, No.20120091110014]。

作者简介:孙伟(1991-), 男, 江苏苏州人, 硕士研究生, 主要从事土地资源管理研究, E-mail: nju_sw@163.com。

通讯作者:金晓斌(1974-), 男, 甘肃兰州人, 副教授, 博士生导师, 主要从事土地资源管理研究, E-mail: jinxb@nju.edu.cn。 
目前, 学术界主要从区域经济视角, 采用宏观 经济指标, 如制造业总产值、就业人数(贺灿飞等, 2010; 陈曦等, 2015)等, 或从企业层面(Ellison et al, 1997; 武前波等, 2010)对制造业的发展进行测度。 在研究内容上, 多围绕一种或几种特定制造业行业 的布局(区位选择、集聚、转移)及其机制、用地效率 等进行探讨。相关研究表明, 城镇化水平是影响制 造业空间分布的重要因素之一(陈曦等, 2015); 制造 业在多项因素共同作用下进行区位选择、集聚与转 移,资源条件、政策环境、要素成本、历史因素、经济 结构、溢出效应、产业联系等因素均可能对其产生 影响 (Smith, 1971; Gordon et al, 2000; 贺灿飞等, 2007; 朱华晟等, 2009; Lu, 2010; 沈静等, 2012; 赵浚 竹等, 2014); 在制造业布局过程中, 制造业用地集 约利用水平与用地效率成为一个突出问题(黄大全 等, 2009; 谢花林等, 2015)。由于中国土地管理的 特殊性, 从土地出让视角探讨城市制造业用地发展 研究, 多为国内学者从城市群或大中城市层面, 对 土地出让与工业地价及产业发展的关系进行分析, 如王家庭等(2012)通过对 2000-2010 年中国 35 个大 中城市的面板数据进行分析, 发现自 2006年工业用 地出让制度改革后, 政府土地供给量对工业地价产 生显著影响; 周霞(2013)通过对京津冀工业制造业 地价与产业高度的实证分析, 指出两者存在显著的 正相关关系, 且耦合程度在不同级别城市有明显差 异; 王贤涁(2014)通过建立一般均衡模型, 发现制造 业较高的资本产出弹性导致较大的土地使用需 求。但现有研究多基于大中尺度, 从更小尺度较全 面地探讨城市群内部基层行政单元制造业土地出 让价格、市场交易情况以及出让规模差异的研究尚 不多见。

产业结构可通过土地利用结构得到映射(Varian, 1992), 土地市场交易的方式、价格、规模和结构, 对区域经济体系内各产业的发展产生鼓励或抑制 作用(周霞, 2013)。制造业用地出让是其扩张的重 要途径, 既包括存量建设用地的再开发, 也包括新 增建设用地的扩张。通过分析不同等级城市制造 业用地的价格水平、活跃水平和规模水平, 可得出 各城市制造业的发展阶段及区域差异产生的原因，
不仅可为认识产业发展规律、制定产业协作模式和 协调发展战略提供参考,而且可为优化区域发展格 局、制定差别化国土开发政策提供决策依据。本文 拟选取长三角、珠三角、京津冀、长江中游以及成渝 五大城市群作为研究区域, 以土地出让为视角, 从 城市、县区 2 个空间尺度分析新增制造业用地的宏 观分布特征及发展差异状况。

\section{2 数据与方法}

\section{1 研究区选择}

《全国城镇体系规划纲要(2005-2020 年)》提出 三大都市连绵区和 13 个城镇群; 《2010 中国城市群 发展报告》进一步提出中国正在形成 23 个城市群 (方创琳等, 2011), 大体勾勒出中国城市群的发展状 况与总体趋势。综合考虑空间分布与区域代表性, 本文选取上述五大国家级城市群作为研究区域, 其 中长三角、珠三角和京津冀代表发展较为成熟的城 市群; 长江中游和成渝城市群分别代表中、西部快 速发展的新兴城市群。研究区共包括 708 个县级行 政单位,其中长三角城市群包括 25 个市共 203 个县 区, 珠三角城市群包括 9 个市共 48 个县区, 京津冀 城市群包括 13 个市共 200 个县区, 长江中游城市群 (含武汉城市圈和环长株潭城市群)包括 17 个市共 111 个县区, 成渝城市群包括 15 个市共 146 个县区。

\section{2 基础数据}

从土地利用角度, 制造业扩张的载体(土地)既 可以通过扩大规模, 以新增的产业用地空间作为对 象; 也可通过存量用地提高利用效率, 以升级改造 方式实现。但由于存量用地数据获取受到限制, 本 文仅对新增制造业用地进行分析。新增制造业用 地数据来自国土资源部 “土地市场网” (www. landchina.com)公布的制造业用地出让信息，包括各 宗地的签定日期、出让位置、供应方式、用地性质 (采用国民经济行业分类 GB/T4754-2002)、宗地面 积、交易金额等 ${ }^{1}$ 。2009-2013 年间, 研究区共出让 制造业用地 8.04 万宗, 总面积 25.19 万 $\mathrm{hm}^{2}$ (表 1 )。

参考中国工业和信息化部对于制造业的分类， 将基于行业分类 GB/T4754 的制造业用地类型合并

(1)本文所采用的制造业用地出让价格是指一级土地市场的成交价格。虽然作为交易价格, 存在因地块位置、公共设施、配套 状态等不同而导致价格差异, 但与居住用地、商业用地等易受市场状况影响、波动性和溢价率较大等显著不同, 制造业用地 市场政府主导性较强,市场化出让制度和工业用地出让最低价标准的基础上,其价格可基本反映政府作用与市场机制间的 关系。 
为原材料工业、消费品工业、装备制造业和电子信

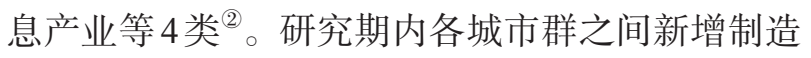
业各类产业用地状况见图 1 。

研究期内, 长三角城市群制造业各产业用地出 让规模占全部研究区的 $47.28 \%$, 其后依次是京津冀 城市群 $(21.63 \%)$ 、成渝城市群(13.75\%)、长江中游城 市群 $(11.33 \%)$ 和珠三角城市群 $(6.01 \%)$ 。就行业类 型而言, 装备制造业和消费品工业的新增用地在各 城市群中均占较大份额, 总比重分别达 $38.10 \%$ 和 $35.63 \%$, 这一现象在长三角城市群尤为明显; 其次 是原材料工业, 比重达 $22.25 \%$, 其中长三角城市群
(8.28\%)与京津冀城市群(7.32\%)相差不大,并高于 其他城市群; 电子信息产业总比重为 $4.01 \%$, 在各城 市群中均为最小。

\section{3 研究方法}

为研究市域尺度下各城市群新增制造业用地 的分布特征, 比较各行业在各城市间的出让规模, 进而确定城市新增用地的相对优势行业,本文采用 区位熵划分各行业在城市群内部的相对优势区。 同时,为定量分析县域尺度下各城市群新增制造业 用地发展差异,选取新增制造业用地价格、交易宗 数及宗地规模分别表征产业发展的价格水平、活跃

表 $12009-2013$ 年研究区制造业用地出让情况

Tab.1 Statistics of manufacturing land transaction in the study areas, 2009-2013

\begin{tabular}{|c|c|c|c|c|c|c|c|c|c|c|}
\hline \multirow{2}{*}{ 年份 } & \multicolumn{2}{|c|}{ 长三角城市群 } & \multicolumn{2}{|c|}{ 珠三角城市群 } & \multicolumn{2}{|c|}{ 京津冀城市群 } & \multicolumn{2}{|c|}{ 长江中游城市群 } & \multicolumn{2}{|c|}{ 成渝城市群 } \\
\hline & 数量/宗 & 面积 $/ \mathrm{hm}^{2}$ & 数量/宗 & 面积 $/ \mathrm{hm}^{2}$ & 数量/宗 & 面积 $/ \mathrm{hm}^{2}$ & 数量/宗 & 面积 $/ \mathrm{hm}^{2}$ & 数量/宗 & 面积 $/ \mathrm{hm}^{2}$ \\
\hline 2009 & 9222 & 19956.26 & 771 & 2565.99 & 1886 & 11843.10 & 920 & 3324.76 & 1194 & 5656.10 \\
\hline 2010 & 11134 & 27928.48 & 902 & 3904.11 & 2074 & 10864.17 & 1331 & 5934.86 & 1437 & 6690.05 \\
\hline 2011 & 9722 & 25843.85 & 800 & 2968.72 & 2282 & 10523.07 & 1588 & 6789.98 & 1781 & 8130.50 \\
\hline 2012 & 10137 & 23985.22 & 698 & 2769.32 & 2408 & 11824.48 & 1636 & 6203.39 & 1499 & 6927.68 \\
\hline 2013 & 9926 & 20839.92 & 744 & 3152.36 & 2960 & 9656.18 & 1681 & 6383.98 & 1668 & 7247.79 \\
\hline 合计 & 50141 & 118553.73 & 3915 & 15360.50 & 11610 & 54711.00 & 7156 & 28636.97 & 7579 & 34652.12 \\
\hline
\end{tabular}

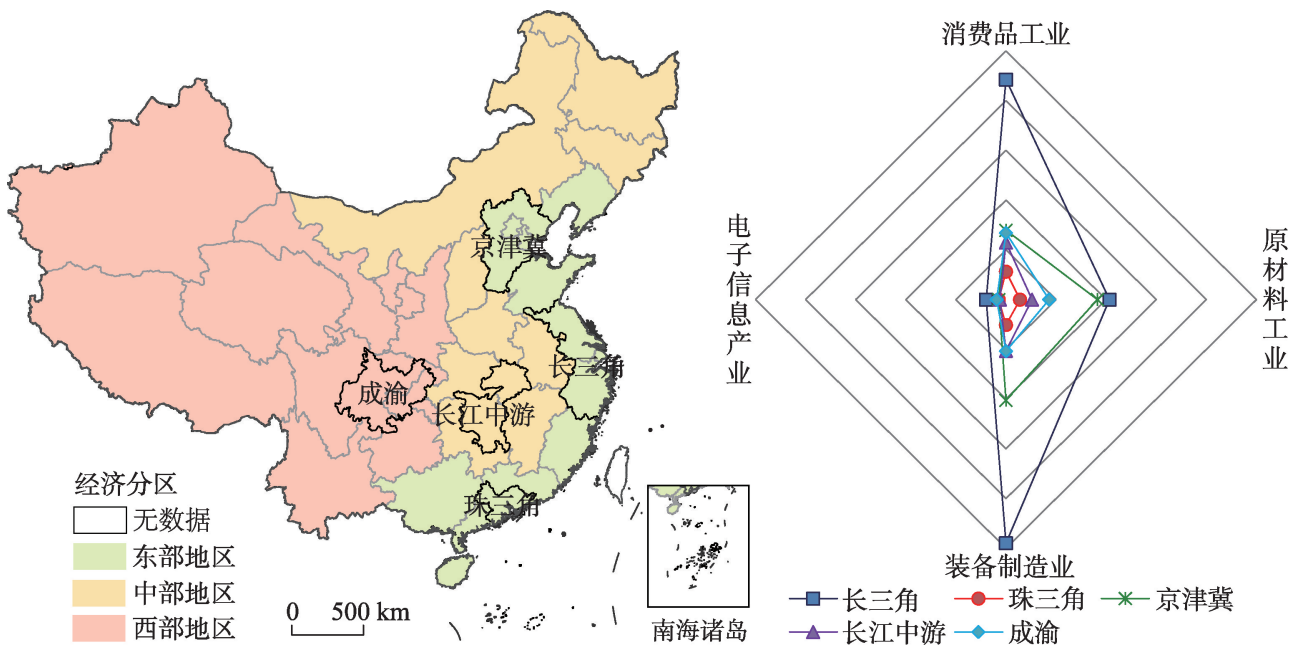

图 1 城市群区位及新增制造业各产业用地规模

Fig.1 Location of urban agglomerations and the size of manufacturing land transaction in four industrial categories

(2)原材料工业包括石油加工、炼焦及核燃料加工业,化学原料及化学制品制造业,非金属矿物制品业,黑色金属冶炼及压延加 工业,有色金属冶炼及压延加工业; 消费品工业包括农副食品加工业, 食品制造业, 饮料制造业, 烟草制造业, 纺织业,纺织 服装、鞋、帽制造业, 皮革、毛皮、羽毛(线)及其制造业, 木材加工及木、竹、藤、棕、草制品业, 家具制造业, 造纸及纸制品业, 印 刷业和记录媒体的复制, 文教体育用品制造业, 医药制造业, 化学纤维制造业, 橡胶制品业, 塑料制品业, 自行车制造业, 电 气机械及器材制造业(家用制冷电器具制造, 家用空气调节器制造, 其他), 仪器仪表及文化、办公用机械制造业, 工艺品及其 他制造业; 装备制造业包括金属制品业, 通用设备制造业, 专用设备制造业, 交通运输设备制造业(铁路运输设备制造业, 汽 车制造, 摩托车制造, 船舶及浮动装置制造, 其他); 电子信息产业包括通讯设备、计算机及其他电子设备制造业。废弃资源 和废旧材料回收加工业由于难以归人上述类型,故予以剔除。 
水平和规模水平, 并通过经济发展指标确定各县区 的中心度及等级, 分析产业发展与县区中心度的耦 合关系; 考虑到基础数据的适用性, 采用皮尔森 (Pearson)相关系数分析新增制造业用地特征指标 与县区中心度的相关性。

\subsection{1 区位熵}

区位熵由哈盖特(P. Haggett)首先提出并运用于 区位分析, 是用于衡量某一区域要素的空间分布状 况以及该区域在上一级区域中的地位与作用的指 标, 可有效地反映各研究样本对于全国平均发展水 平的差异(引自乌铁红等, 2009)。其计算公式为:

$$
\alpha=\frac{S_{i j} / \sum_{j=1}^{m} S_{i j}}{\sum_{i=1}^{n} S_{i j} / \sum_{i} \sum_{j} S_{i j}}
$$

式中: $\alpha$ 为区位熵； $S_{i j}$ 表示第 $i$ 个城市第 $j$ 个产业 的出让规模; $m$ 表示总产业数; $n$ 表示研究区城市 总数。当 $\alpha>1$ 时, 表示该城市的这一产业在整个 研究区中在用地增量上具有相对优势。

\subsection{2 耦合分析}

(1) 城市群城镇体系与中心等级划分

基于评价指标的可得性和统计口径一致性, 从 县区人口分布、经济发展、产业结构、收人和消费水 平、投资能力、基础设施以及城市开发等 7 个方面, 以 2010 年为基准, 选取人口密度、人均 GDP、城镇 单位就业人员、地方财政一般预算收人、第二产业 产值、第三产业产值、城镇居民人均可支配收人、城 镇单位就业人员平均工资、社会消费品零售总额、 全社会固定资产投资,道路密度和国土开发度等 12 项指标 $^{3}$, 采用熵值法确定权重计算各县区的中心
度(曾春水, 2013), 结合各城市群规划中确定的城市 等级和《全国工业用地出让最低价标准》中规定的 土地等别,将各城市群内的县区划分为核心县区、 次核心县区、骨干县区和一般县区 4 个等级,划分结 果如图 2所示。

\section{(2) 新增制造业用地发展特征指标}

地价是地租的资本化,地价高低反映出不同的 用地竞争, 制造业用地价格水平在一定程度上体现 了制造业用地市场化竞争程度以及市场配置关系; 活跃水平表示土地市场的交易频繁度,可反映不同 产业的发展方向; 规模水平一定程度上反映了区域 产业用地限制,一般而言,城市核心区域地价水平 高, 低端产业承担租金能力弱, 其规模相对较小。 各指标具体释义见表 2 。此外,为进一步分析各县 区制造业用地的市场化程度, 应比较出让价格与最 低工业出让价格, 以检验各城市群中各类产业的市 场机制发挥程度。

(3) 皮尔森(Pearson)相关系数

Pearson 相关系数是一种用来衡量 2 个数据集 合之间相似性的统计学方法。相关系数反映了 2 个 变量线性的相关程度,其大小由 $r$ 值决定。其计算 公式为:

$$
r=\frac{\sum X Y-\frac{\sum X \sum Y}{N}}{\sqrt{\left(\sqrt{\left.\sum X^{2}-\frac{\left(\sum X\right)^{2}}{N}\right)\left(\sum Y^{2}-\frac{\left(\sum Y\right)^{2}}{N}\right)}\right.}}
$$

式中: $r$ 为相关系数值; 变量 $X$ 为所有点的 $x$ 坐标的 集合, 变量 $Y$ 为所有点的 $y$ 坐标的集合; $N$ 表示点 的总个数。

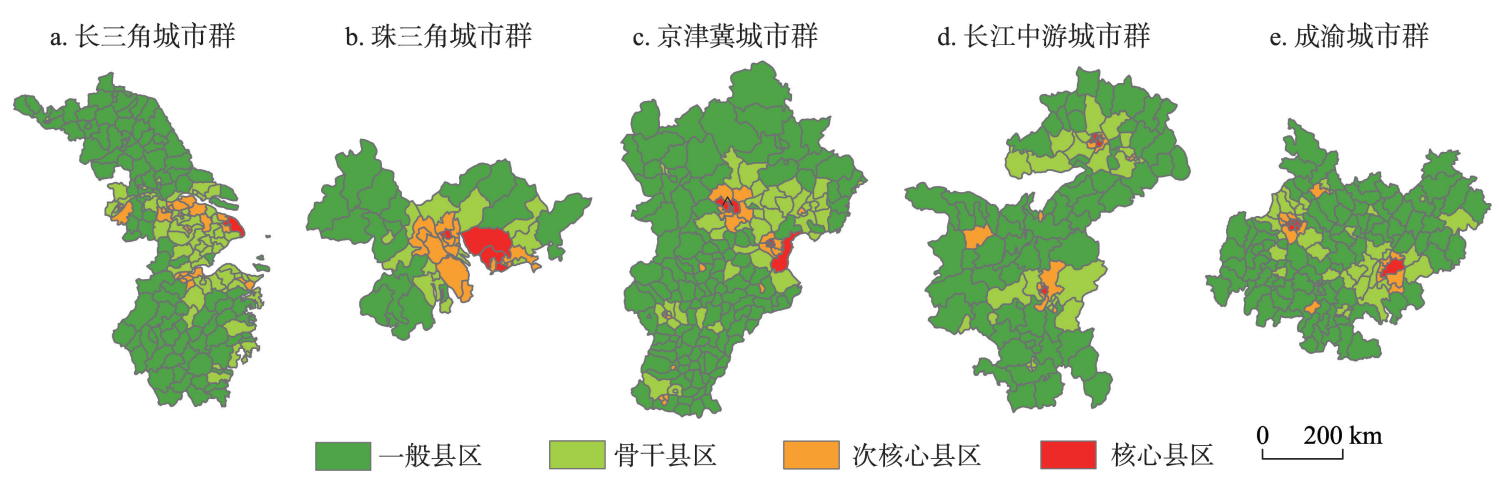

图 2 各城市群县区等级划分

Fig.2 Classification of counties of urban agglomerations

(3)数据主要来源于《2010年中国区域经济年鉴》, 部分缺失数据通过《2010年国民经济和社会发展统计公报》及《2010年统计 年鉴》插补。 
表 2 新增制造业用地发展特征指标及其含义

Tab.2 Evaluation indicators of new manufacturing land development

\begin{tabular}{|c|c|c|c|}
\hline 指标 & 指标名称 & 计算公式 & 说明 \\
\hline$X_{1}$ & 价格水平 $/\left(\right.$ 元 $\left./ \mathrm{m}^{2}\right)$ & $\frac{\sum P_{i j}}{N_{i j}}$ & $\begin{array}{l}\text { 表征制造业用地出让价格平均水平。其中 } P_{i j} \text { 表示研究期内第 } j \text { 个城市群内研究单元 } \\
i \text { 各宗地的成交地价; } N_{i j} \text { 表示研究期内第 } j \text { 个城市群内研究单元 } i \text { 的总交易宗数。 }\end{array}$ \\
\hline$X_{2}$ & 活跃水平/宗 & $N_{i j}$ & $\begin{array}{l}\text { 表征制造业用地出让的数量, 代表市场活跃水平。其中 } N_{i j} \text { 表示研究期内第 } j \text { 个城市 } \\
\text { 群内研究单元 } i \text { 的总交易宗数。 }\end{array}$ \\
\hline$X_{3}$ & 规模水平/(hm²/宗) & $\frac{\sum S_{i j}}{N_{i j}}$ & $\begin{array}{l}\text { 表征制造业用地出让的平均规模。其中 } S_{i j} \text { 表示研究期内第 } j \text { 个城市群内研究单元 } i \\
\text { 各宗地的出让规模; } N_{i j} \text { 表示研究期内第 } j \text { 个城市群内研究单元 } i \text { 的总交易宗数。 }\end{array}$ \\
\hline$X_{4}$ & 工业最低出让价格 $/\left(\right.$ 元 $\left./ \mathrm{m}^{2}\right)$ & l & $\begin{array}{l}\text { 根据《全国工业用地出让最低价标准》(国土资发(2009)56号), 将全国分为 } 15 \text { 个级别, } \\
\text { 确定各县区工业用地最低出让价格。 }\end{array}$ \\
\hline
\end{tabular}

3 城市群新增制造业用地分布特征

为从市域尺度分析城市群新增制造业用地的 宏观分布特征, 以点密度形式呈现各城市新增制造 业各行业用地的出让规模(点越密集, 表示出让的 绝对规模越大), 各行业用地规模在各城市中的数 量大小关系可体现城市群内部的协调性; 依据出让 绝对规模, 通过区位熵指标研究行业相对关系, 以 区位熵值大于 1 的城市表征各城市群内产业新增用 地的相对优势区(图 3)。

由图 3 可知, 在市级尺度上, 就新增产业用地的 规模而言, 珠三角城市群内部各市分布较为协调; 而长三角城市群中, 除浙南发展较弱外, 内部其他 城市分布也较为协调; 京津冀城市群的新增产业用 地主要集中在天津及周边; 长江中游城市群主要位 于武汉、长沙及其周边地区; 成渝城市群多集中在 重庆、成都及其周边地区。

长三角与珠三角城市群发展较为成熟, 内部各 城市的功能定位及产业发展布局也较为明确, 因而 新增行业布局总体较为协调; 京津冀城市群产业整 体发展协调性有待提升, 可能因为近年来天津滨海 新区制造业发展迅猛, 吸纳并集聚了京津冀城市群 的大部分新增行业,一定程度上导致河北各市产业 发展弱化; 长江中游城市群作为实现中部崛起战略 的重要依托, 产业发展多集中在核心城市, 但辐射 效应相对较弱, 总体而言武汉城市群优于长株潭城 市群; 成渝城市群作为西部大开发的重点区域, 核 心及周边城市产业发展旺盛, 但辐射带动作用仍有 待加强。就核心城市而言, 长三角和珠三角城市群 中的核心城市多以产业转型升级为主要目标, 上 海、南京、杭州、广州等城市各类产业尤其是传统产 业发展相对较慢; 北京和天津虽都为京津冀城市群 核心城市, 但功能定位差别较大。北京作为中国政
治、文化与科技中心, 因疏解非首都功能, 制造业发 展相对较慢, 而天津作为先进制造业研发基地和改 革先行示范区, 制造业发展极为旺盛; 长江中游与 成渝城市群中的核心城市是其区域发展的重要增 长极, 长沙、武汉、成都、重庆各类产业发展均较为 旺盛, 但产业辐射广度和深度仍需进一步提升。

就新增用地的相对优势产业(即产业相对优势 区)分布而言,整体呈现出一定的空间特征。电子 信息产业和装备制造业的新增用地相对优势区主 要集中在城市群的核心及周边辐射区域,这些地区 的城市等级较高, 经济总量规模较大, 城市发展态 势较好; 原材料工业主要位于城市群的边缘城市, 一般城市等级较低, 经济发展水平也相对较弱; 消 费品工业新增用地的相对优势区则分布较广。同 时, 产业相对优势区也存在一定的重叠, 主要表现 为电子信息产业和装备制造业的重叠、装备制造业 和原材料工业的重叠, 以及各产业与消费品工业的 重叠, 在一定程度上反映出产业演变具有过渡性。 消费品工业作为民生产业在各城市、各发展阶段都 具有重要作用, 且具有持久性。就差异性而言, 原 材料工业新增用地相对优势区在长三角和珠三角 城市群分布范围较小, 而在京津冀和成渝城市群则 较广; 电子信息产业新增用地在长三角、珠三角、长 江中游和成渝城市群主要分布在核心城市及其周 边辐射城市, 而在京津冀城市群中相对优势区仅分 布在核心城市。

\section{4 城市群新增制造业用地发展与城镇 体系的耦合特征}

\section{1 特征指标一县区中心度变化曲线分析}

以县区中心度作为横坐标, 以各特征参数值 (价格水平、活跃水平和规模水平)为纵坐标绘制曲 

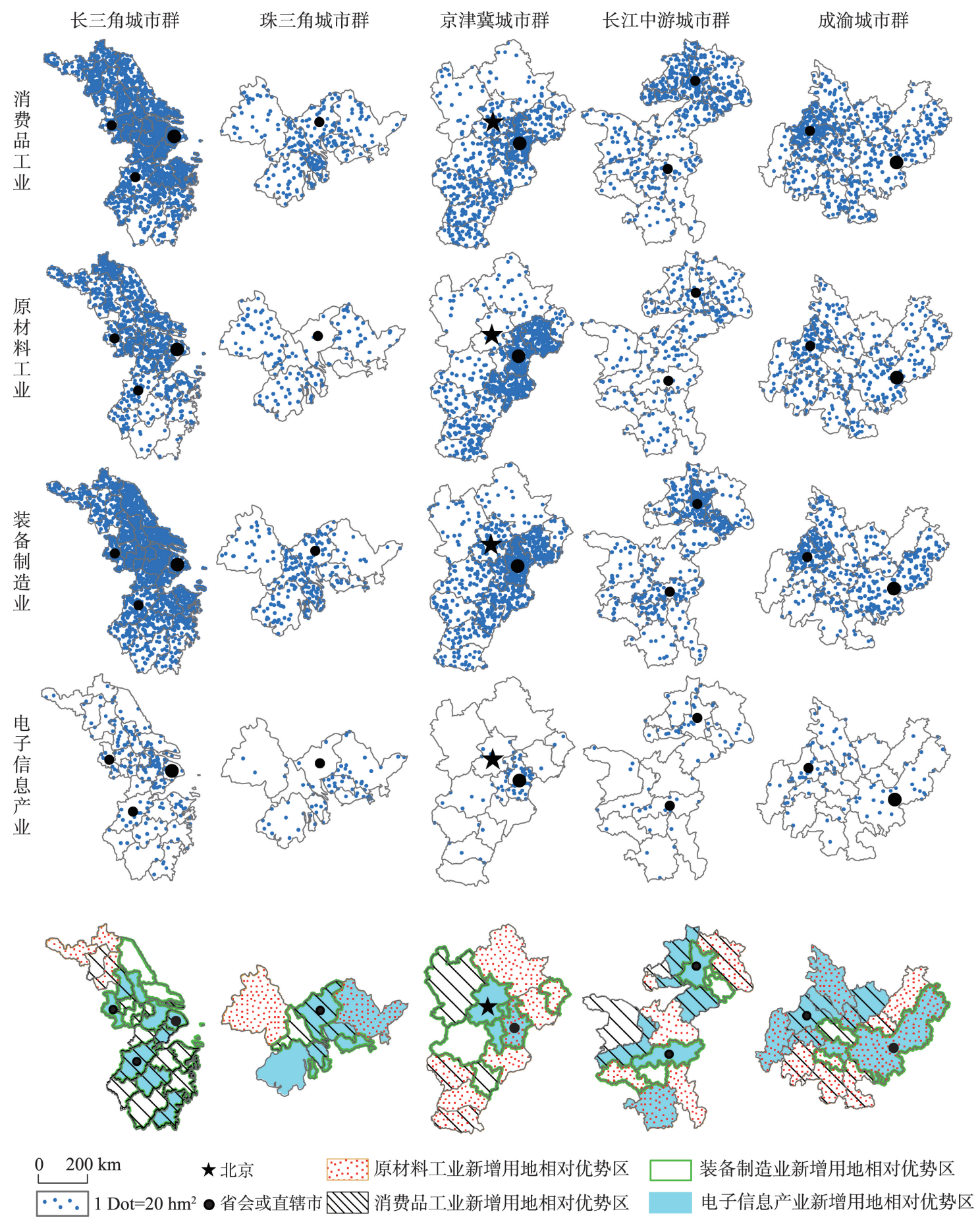

图 3 城市群新增产业用地宏观布局特征

Fig.3 Characteristics of regional distribution of new manufacturing land in urban agglomerations

线,可反映 3 项指标在不同中心等级县区的具体变 化趋势, 以此体现制造业新增用地发展的区域差 异,计算结果如图 4所示。

(1) 价格水平一县区中心度

就变化趋势而言, 城市群中县区地价总体呈现 随等级提升而递增的趋势, 表明城市群制造业用地
整体上体现了市场配置作用,但在城市群中特定等 级的县区也存在差别, 如长三角和成渝城市群的骨 干县区和次核心县区之间、京津冀城市群的次核心 县区和核心县区之间等。具体表现为部分城市群 内部县区虽等级提升但地价无变化甚至下降的趋 势, 这可能与该县区存在政府压低出让价格促进招 
商引资等问题有关。同时,制造业用地价格与产业 类型密切相关, 在各城市群产业中表现出不同的价 格梯度。

就各产业地价与最低工业出让价格比较而言, 珠三角城市群各产业地价均高于工业用地最低出 让价, 表明其制造业用地市场竞争相对充分; 长三 角城市群的电子信息产业,尤其是核心县区的地价 低于工业用地最低出让价, 这可能与部分地区将电 子信息产业作为提升地方形象、促进地方就业、增 加地方税收的产业类型,地方政府倾向于采用筑巢 引凤、降低门槛等吸引投资的措施有关; 京津冀城 市群在核心县区出现各产业地价均低于工业用地 最低出让价的情况, 表明其制造业用地市场化程度
较低, 土地出让成为政府主导下的行政规划控制行 为; 长江中游城市群的电子信息产业和原材料工业 在次核心和核心县区的地价低于最低出让价; 成渝 城市群在次核心县区地价偏低,从侧面反映出新兴 城市群为加快发展, 形成产业集聚和区域优势, 有 意识地降低了土地出让价格。

就地价水平而言, 长三角与珠三角城市群明显 高于其他城市群,尤其在核心县区,表明这 2 个城市 群的制造业已进人较为成熟的发展阶段,其发展更 多地依靠市场化手段,政府干预相对较少。

(2) 活跃水平一县区中心度

就变化趋势而言,各城市群中的核心县区较其 他等级县区的市场活跃度低,可能是由于核心县区


一电子信息产业 一消费品工业—原材料工业—装备制造业一最低工业出让价

一般县区 - 骨干县区 次核心县区 - 核心县区

图 4 特征指标一县区中心度耦合曲线

Fig.4 Coupling curve of county classes and evaluation indicators 
大多位于城市主城区或中心城区, 其经济发展程度 一般较高, 多重点发展服务业, 导致制造业不断向 外转移所致。长三角和珠三角城市群在一般县区 和骨干县区交易最活跃, 可能是由于这两大城市群 发展较为成熟, 工业化水平较高, 工业扩展迅速,一 般县区和骨干县区承接核心县区和次核心县区产 业转移的能力均较强。京津冀、长江中游和成渝城 市群在骨干县区和次核心县区交易最多, 可能是由 于其核心区的辐射效应仍较弱, 工业扩散程度较 低, 主要通过经济潜力相对较大的骨干县区和次核 心县区承接核心县区的产业转移。

就行业而言, 新增原材料工业偏向于在一般县 区和骨干县区集聚, 新增电子信息产业偏向于往骨 干县区和次核心县区发展。表明新增产业类型的 集聚特征与县区等级有一定的关系, 县区等级越 低, 越容易被动承接较落后的产能; 县区等级越高, 产业转型升级的需求越大, 较易发展新兴产业。

就活跃量而言, 在区域分布上, 长三角城市群 的县区出让数远高于其他城市群; 在产业类型上, 以消费品工业和装备制造业交易量相对较多。

\section{(3) 规模水平一县区中心度}

相对于活跃水平, 城市群制造业用地的平均出 让规模在各县区等级及产业间的表现虽没有明显 规律, 但也存在一定的特征。如原材料工业用地的 平均出让规模在一般县区或骨干县区最大, 除京津 冀城市群外, 其余城市群均随县区等级提升呈现下 降趋势, 这可能因为作为低端产能, 其在低等级县 区更易实现规模效益。装备制造业用地的平均出
让规模在各城市群的核心县区最大。此外,除长江 中游城市群外, 电子信息产业均在核心县区最大, 而核心县区市场活跃度较低, 表明装备制造业和电 子信息产业在核心县区实现了较高的规模化程度。

\section{2 特征指标一县区中心度相关性分析}

为进一步验证各城市群各类产业用地与县区 中心度之间的关联性, 采用 Pearson 相关系数判断 城市群各行业地价水平、活跃水平、规模水平与县 区中心度之间的相关程度(表3)。

由表 3 可知, 5 个城市群各类产业地价水平与 县区中心度存在显著的正相关性, 其中弱相关性 $(r$ 为 $0.2 \sim 0.4$ )约占 $20 \%$, 主要集中在电子信息产业; 中 等相关性 $(r$ 为 $0.4 \sim 0.6)$ 占比达 $50 \%$, 大多集中在消费 品工业和原材料工业; 强相关性 $(r$ 为 $0.6 \sim 0.8)$ 占比 约 $30 \%$, 分别是珠三角城市群的电子信息产业, 成 渝的消费品工业, 以及长三角、珠三角、京津冀和成 渝城市群的装备制造业。总体来说，电子信息产业 地价水平与县区中心度的相关性较弱, 装备制造业 地价水平与县区中心度的相关性较高。

就活跃水平而言, 大多数城市群产业与县区中 心度之间无显著相关性。仅成渝城市群的电子信 息产业与县区中心度存在微弱正相关 $(r$ 为 $0.0 \sim 0.2)$; 长江中游城市群的消费品工业, 以及长三角和长江 中游城市群的原材料工业与县区中心度之间存在 微弱负相关 $(r$ 为 $-0.2 \sim 0.0)$ 。

就规模水平而言, 原材料用地的平均出让规模 在各城市群与县区中心度均呈一定的负相关性, 并 在珠三角城市群达到中等强度 $(r$ 为 $-0.6 \sim-0.4)$ 。此

表 3 特征指标一县区中心度相关性

Tab.3 Correlation between county classes and evaluation indicators

\begin{tabular}{|c|c|c|c|c|c|c|c|c|c|c|c|}
\hline & & \multicolumn{2}{|c|}{ 长三角县区中心度 } & \multicolumn{2}{|c|}{ 珠三角县区中心度 } & \multicolumn{2}{|c|}{ 京津冀县区中心度 } & \multicolumn{2}{|c|}{ 长江中游县区中心度 } & \multicolumn{2}{|c|}{ 成渝县区中心度 } \\
\hline & & 相关系数 & Sig. & 相关系数 & Sig. & 相关系数 & Sig. & 相关系数 & Sig. & 相关系数 & Sig. \\
\hline \multirow{3}{*}{$\begin{array}{l}\text { 电子信 } \\
\text { 息产业 }\end{array}$} & 地价水平 & $0.356^{* *}$ & 0.000 & $0.652^{* *}$ & 0.000 & $0.335^{* *}$ & 0.007 & $0.382^{* *}$ & 0.001 & $0.459^{* * *}$ & 0.000 \\
\hline & 活跃水平 & 0.095 & 0.177 & 0.174 & 0.236 & 0.083 & 0.241 & -0.103 & 0.284 & $0.139^{*}$ & 0.095 \\
\hline & 规模水平 & -0.037 & 0.600 & -0.217 & 0.138 & $0.287^{* *}$ & 0.000 & $-0.167^{*}$ & 0.080 & 0.115 & 0.168 \\
\hline \multirow{3}{*}{$\begin{array}{l}\text { 消费品 } \\
\text { 工业 }\end{array}$} & 地价水平 & $0.557^{* *}$ & 0.000 & $0.500^{* *}$ & 0.001 & $0.533^{* *}$ & 0.000 & $0.453^{* *}$ & 0.000 & $0.646^{* *}$ & 0.000 \\
\hline & 活跃水平 & -0.104 & 0.142 & 0.074 & 0.616 & 0.016 & 0.823 & $-0.167^{*}$ & 0.080 & -0.050 & 0.547 \\
\hline & 规模水平 & -0.058 & 0.412 & -0.217 & 0.138 & -0.079 & 0.263 & $-0.325^{* *}$ & 0.002 & -0.050 & 0.548 \\
\hline \multirow{3}{*}{$\begin{array}{l}\text { 原材料 } \\
\text { 工业 }\end{array}$} & 地价水平 & $0.537^{* *}$ & 0.000 & $0.547^{* *}$ & 0.000 & $0.360^{* *}$ & 0.000 & $0.492^{* *}$ & 0.000 & $0.568^{* *}$ & 0.000 \\
\hline & 活跃水平 & $-0.132^{*}$ & 0.061 & -0.232 & 0.112 & 0.052 & 0.468 & $-0.293^{* * *}$ & 0.002 & -0.131 & 0.114 \\
\hline & 规模水平 & $-0.149^{*}$ & 0.034 & $-0.497^{* *}$ & 0.000 & -0.025 & 0.729 & $-0.325^{* *}$ & 0.000 & $-0.216^{* *}$ & 0.009 \\
\hline \multirow{3}{*}{$\begin{array}{l}\text { 装备制 } \\
\text { 造业 }\end{array}$} & 地价水平 & $0.678^{* * *}$ & 0.000 & $0.735^{* *}$ & 0.000 & $0.617^{* *}$ & 0.000 & $0.564^{* * *}$ & 0.000 & $0.615^{* *}$ & 0.000 \\
\hline & 活跃水平 & -0.013 & 0.856 & 0.022 & 0.883 & 0.046 & 0.516 & -0.088 & 0.357 & 0.102 & 0.218 \\
\hline & 规模水平 & -0.106 & 0.132 & -0.158 & 0.284 & 0.002 & 0.974 & $0.433^{* *}$ & 0.000 & -0.013 & 0.880 \\
\hline
\end{tabular}

注:***分别表示在 $0.01 、 0.1$ 水平(双侧)上显著相关。 
外,京津冀城市群的县区中心度与电子信息产业呈 弱正相关; 长江中游城市群的县区中心度与消费品 工业呈弱负相关, 与装备制造业呈中等正相关。

通过价格水平、活跃水平、规模水平与县区中 心度的耦合关系可一定程度上解释城市群各制造 业新增用地的分布特征。长三角和珠三角城市群 发展的协调性优于其他 3 个城市群, 表现在长三角 和珠三角城市群在更低等级县区交易相对活跃; 新 增电子信息等新兴产业用地主要集中于核心城市 及周边辐射城市, 原材料等传统产业新增用地则更 倾向于分布在城市群的边缘城市。

\section{5 结论与讨论}

\section{1 结论}

本文以长三角、珠三角、京津冀、长江中游及成 渝等 5 个国家级城市群作为研究区域, 从土地出让 视角分析了 2009-2013 年上述城市群新增制造业用 地的分布特征及价格水平、活跃水平、规模水平与 县区中心等级耦合特征的差异, 得出以下主要 结论。

(1) 就分布特征而言, 在区域上, 长三角和珠三 角城市群发展较为成熟, 制造业发展布局和产业分 工较为合理, 竞争优势相对较大; 而京津冀、长江中 游和成渝城市群的协调性仍有较大提升空间, 呈现 出由少数中心城市控制的发展孤岛。在产业上, 新 增制造业各类行业用地在各城市群均呈现一定的 集聚特征,其中电子信息产业和装备制造业主要在 核心城市及其周边辐射城市布局; 而新增原材料工 业则主要在边缘城市具有比较优势。各城市群新 增制造业各类行业用地的分布与区域(城市)等级具 有一定的相关性。

(2) 就产业用地发展与区域等级的耦合特征而 言, 在价格水平上, 各城市群各类行业地价水平与 县区中心度存在显著的正相关性, 新增制造业用地 整体在市场化机制配置上取得了积极作用。长三 角和珠三角城市群制造业用地市场化水平较高, 珠 三角城市群市场化竞争较为充分。制造业用地价 格与区域(城市、县区) 等级及行业类型密切相关, 不 同区域下政府对不同行业的用地控制方式存在差 异。在活跃水平上, 各城市群核心县区制造业用地 市场活跃性均最弱, 长三角和珠三角城市群在一般 县区和骨干县区活跃度最高, 而京津冀、长江中游
和成渝城市群在骨干县区及次核心县区最为活 跃。新增行业集聚与不同等级区存在一定的导向， 原材料等传统产业趋于向低等级区发展,电子信息 产业等新兴产业易集聚在较高等级区。在规模水 平上,原材料工业在一般县区或骨干县区的平均规 模比其他等级区大,而电子信息产业、装备制造业 在核心县区相对较大。

\section{2 讨论}

在中国工业化和城镇化进程中,城市群以产业 为纽带通过核心城市辐射带动其他等级城市, 不同 等级城市的协调发展、产业的合理布局事关中国全 面建成小康社会的大局。区域发展规划对城市产 业分工、产业空间布局具有重要的引导和调控作 用,而土地管理政策作为促进土地资源优化配置的 重要政策手段,在统筹区域发展、增强区域竞争力 方面能发挥重要作用。针对城市群制造业发展中 出现的区域不协调状况,应着力提升核心城市的溢 出效应, 加强关注边缘城市的发展状况, 培养区域 次核心, 促进产业有序转移, 优化国土开发空间结 构, 促进城市和产业的协调发展。在土地资源配置 的同时,应充分考虑工业制造业用地市场, 考虑到 工业用地价格远低于商住用地价格, 竞价机制市场 化程度较低, 需加强要素市场的调控管理, 通过土 地价格梯度差影响企业生产成本梯度差, 进而形成 合理、有序的城际间产业布局梯度, 并进而由产业 高度差反作用于土地价格, 不断促进城市群内产业 结构和土地利用结构双优化。

由于基础数据可获取性的限制, 本文仅对新增 制造业用地进行分析，难以全面充分地反映制造业 的实际扩张, 尤其是经济较为发达的地区, 面临内 城工业转型升级的压力, 部分(甚至是较大比例)新 增制造业用地是由存量制造业用地调整而得, 致使 新增制造业用地难以反映区域产业发展的实际用 地扩张; 同时相对简单的行业类型划分也难以凸显 产业高级化进程。后续将在细化制造业分类的基 础上, 结合存量制造业用地规模和用地效率等内容 进一步深化研究。

\section{参考文献(References)}

陈䂀, 席强敏, 李国平. 2015. 城镇化水平与制造业空间分 布: 基于中国省级面板数据的实证研究 [J]. 地理科学, 35 (3): 259-267. [Chen X, Xi Q M, Li G P. 2015. Urbanization level and spatial distribution of manufacturing industry: An empirical research based on provincial panel data 
[J]. Scientia Geographica Sinica, 35(3): 259-267.]

党兴华, 郭子彦, 赵璟. 2007. 基于区域外部性的城市群协调

发展 $[\mathrm{J}$ ]. 经济地理, 27(3): 463-466, 475. [Dang X H, Guo

Z Y, Zhao J. 2007. Research on congruous development of urban agglomeration based on regional externalities[J].

Economic Geography, 27(3): 463-466, 475.]

方创琳, 姚士谋, 刘盛和, 等. 2011. 2010 中国城市群发展报

告[M]. 北京: 科学出版社. [Fang C L, Yao S M, Liu S H, et al. 2011. 2010 Zhongguo chengshiqun fazhan baogao

[M]. Beijing, China: Science Press.]

傅元海, 叶祥松, 王展祥. 2014. 制造业结构优化的技术进步路

径选择: 基于动态面板的经验分析 [J]. 中国工业经济, (9):

78-90. [Fu Y H, Ye X S, Wang Z X. 2014. The selection of technology progress path of manufacturing structure optimization: An empirical analysis based on dynamic panel data model[J]. China Industrial Economics, (9): 78-90.]

顾朝林. 2011. 城市群研究进展与展望 [J]. 地理研究, 30(5):

771-784. [Gu C L. 2011. Study on urban agglomeration:

Progress and prospects[J]. Geographical Research, 30(5): 771-784.]

国家发改委国地所课题组. 2009. 我国城市群的发展阶段与 十大城市群的功能定位 [J]. 改革, (9): 5-23. [The Academic Group of Territorial Development and Regional Economic Development Institution in National Development and Reform Commission. 2009. The developing stage of and function orientation of ten Chinese urban cluster[J]. Reform, (9): 5-23.]

贺灿飞, 潘峰华, 孙蕾. 2007. 中国制造业的地理集聚与形成 机制 [J]. 地理学报, 62(12): 1253-1264. [He C F, Pan F H, Sun L. 2007. Geographical concentration of manufacturing industries in China[J]. Acta Geographica Sinica, 62(12): 1253-1264.]

贺灿飞, 朱彦刚, 朱晟君. 2010. 产业特性、区域特征与中国 制造业省区集聚[J]. 地理学报, 65(10): 1218-1228. [He C F, Zhu Y G, Zhu S J. 2010. Industrial attributes, provincial characteristics and industrial agglomeration in China[J]. Acta Geographica Sinica, 65(10): 1218-1228.]

黄大全, 洪丽璇, 梁进社. 2009. 福建省工业用地效率分析与 集约利用评价 [J]. 地理学报, 64(4): 479-486. [Huang D Q, Hong L X, Liang J S. 2009. Analysis and evaluation of industrial land efficiency and intensive use in Fujian Province[J]. Acta Geographica Sinica, 64(4): 479-486.]

马延吉. 2010. 辽中南城市群产业集聚发展与格局 [J]. 经济 地理, 30(8): 1294-1298. [Ma Y J. 2010. Development and pattern of industrial agglomeration in central and southern Liaoning[J]. Economic Geography, 30(8): 1294-1298.] 沈静, 向澄, 柳意云. 2012. 广东省污染密集型产业转移机 制: 基于 2000-2009 年面板数据模型的实证 [J]. 地理研 究, 31(2): 357-368. [Shen J, Xiang C, Liu Y Y. 2012. The mechanism of pollution- intensive industry relocation in
Guangdong Province, 2000- 2009[J]. Geographical Research, 31(2): 357-368.]

王家庭, 曹清峰, 田时嫣. 2012. 产业集聚、政府作用与工业 地价: 基于 35 个大中城市的经验研究 $[\mathrm{J}]$. 中国土地科学, 26(9): 12-20. [Wang J T, Cao Q F, Tian S Y. 2012. Industrial agglomeration, government intervention and industrial land prices: An empirical study on 35 cities in China[J]. China Land Sciences, 26(9): 12-20.]

王贤涁. 2014. 土地出让与产业发展 [J]. 经济管理, (1): 1221. [Wang X B. 2014. Land lease and industry development[J]. Economic Management Journal, (1): 12-21.]

乌铁红, 张捷, 李文杰, 等. 2009. 中国人境旅游经济发展水 平的空间格局演变及成因: 基于人境旅游经济区位熵的 分析[J]. 干旱区资源与环境, 23(5): 189-194. [Wu T H, Zhang J, Li W J, et al. 2009. The spatial pattern evolution of the inbound tourism economic development level and the causes in China: Based on the inbound tourism economic entropy analysis[J]. Journal of Arid Land Resources and Environment, 23(5): 189-194.]

武前波, 宁越敏. 2010. 中国制造业企业 500 强总部区位特征 分析[J]. 地理学报, 65(2): 139-152. [Wu Q B, Ning Y M. 2010. Headquarter locations of top 500 enterprises of Chinese manufacturing industries[J]. Acta Geographica Sinica, 65(2): 139-152.]

谢花林, 王伟, 姚冠荣, 等. 2015. 中国主要经济区城市工业 用地效率的时空差异和收玫性分析[J]. 地理学报, 70(8): 1327-1338. [Xie H L, Wang W, Yao G R, et al. 2015. Spatial and temporal differences and convergence of China's main economic zones[J]. Acta Geographica Sinica, 70(8): 1327-1338.]

曾春水. 2013. 京津冀城市群城市规模等级与服务业发展差 异[D]. 北京: 首都师范大学. [Zeng C S. 2013. Urban size hierarchy and service industry development differences in Beijing- Tianjin- Hebei Urban Agglomeration[D]. Beijing, China: Capital Normal University.]

赵浚竹, 孙铁山, 李国平. 2014. 中国汽车制造业集聚与企业 区位选择[J]. 地理学报, 69(6): 850-862. [Zhao J Z, Sun T S, Li G P. 2014. Agglomeration and firm location choice of China's automobile manufacturing industry[J]. Acta Geographica Sinica, 69(6): 850-862.]

周霞. 2013. 城市群工业地价与产业结构高级化的互动机理 研究: 以京津冀城市群为例 $[D]$. 北京: 首都经济贸易大 学. [Zhou X. 2013. The research on interaction mechanism between manufacturing industry land price and the promoting of industrial structure in urban agglomerations: A case of Beijing- Tianjin- Hebei Urban Agglomeration[D]. Beijing, China: Capital University of Economics and Business.]

朱华戟, 王缉慈, 李鹏飞, 等. 2009. 基于多重动力机制的集 群企业迁移及区域影响: 以温州灯具企业迁移中山古镇 
为例 [J]. 地理科学进展, 28(3): 329-336. [Zhu H S, Wang J C, Li P F, et al. 2009. Firm migration of clusters in east coastal areas of China: A case study of lamp-making clusters in Wenzhou, Zhejiang[J]. Progress in Geography, 28 (3): 329-336.]

Ellison G, Glaeser E L. 1997. Geographic concentration in U.S. manufacturing industries: A dartboard approach $[\mathrm{J}]$. Journal of Political Economy, 105(5): 889-927.

Gordon I R, McCann P. 2000. Industrial clusters: Complexes, agglomeration and/or social networks[J]. Urban Studies, 37 (3): 513-532.

Lu J Y. 2010. Agglomeration of economic activities in China: Evidence from establishment censuses[J]. Regional Studies, 44(3): 281-297.

Smith D M. 1971. Industrial location: An economic geographical analysis[M]. New York: John Wiley \& Sons.

Varian H R. 1992. Microeconomic analysis[M]. 3rd ed. New York: W.W. Norton \& Company: 24-26.

\title{
Characteristics of new manufacturing land and coupling analysis with urban system in Chinese major urban agglomerations
}

\author{
SUN Wei ${ }^{1}$, JIN Xiaobin ${ }^{1,2^{*}}$, ZHANG Zhihong ${ }^{1,3}$, HAN Juan' ${ }^{1}$, XIANG Xiaomin ${ }^{1}$, ZHOU Yinkang ${ }^{1,2}$ \\ (1. College of Geographic and Oceanographic Sciences, Nanjing University, Nanjng 210023, China; \\ 2. Research Center of Natural Resources, Nanjing University, Nanjng 210023, China; \\ 3. China Land Surveying and Planning Institute, Beijing 100029, China)
}

\begin{abstract}
China has experienced rapid industrial development, especially in manufacturing. Formation of China's emerging urban agglomerations has relied on this development along with the expansion of manufacturing land. In order to explore the structure and layout conditions of new manufacturing land as well as functional division status, based on the data of manufacturing land transaction collected from China's land market from 2009 to 2013, this study analyzes the characteristics and development of new manufacturing land in five major urban agglomerations - the Yangtze River Delta, the Pearl River Delta, the Beijing-Tianjin-Hebei region, the middle reach of the Yangtze River, and the Chengdu-Chongqing area. The location entropy method was used to explore land distribution characteristics at the city level. Coupled with urban system, three evaluation indicators - price level, level of activity, and scale were selected to analyze the development discrepancies at the county level. Pearson correlation coefficient method was further adopted for quantitative analysis. The results show that: (1) New manufacturing land differed significantly among the urban agglomerations. Development in the Yangtze River Delta and the Pearl River Delta is balanced. The BeijingTianjin-Hebei region, the middle reach of the Yangtze River, and the Chengdu-Chongqing area showed poor coordination. (2) Each industrial category presents the characteristics of spatial clustering in all urban agglomerations. The raw materials industry is mostly concentrated in the peripheral cities of urban agglomerations and the low-grade land areas within cities, while electronic information industry tends to distribute in the core cities of urban agglomeration and the high-grade land areas within cities. (3) Market mechanism is present in new manufacturing land acquisition, where land price follows the value (grade) of land. There has been very limited manufacturing land transaction in the core urban areas, and the most active market transaction generally occurred immediately outside the core urban areas. The conclusions could provide some references for adjusting and optimizing industrial layout, and coordinate development strategies in regions of different industrial development levels.
\end{abstract}

Key words: land transaction; manufacturing; new manufacturing land; coupling characteristics; urban agglomeration; China 